\title{
MEDIA GRAFIS KARTU PADA MATERI MENGHARGAI JASA DAN PERANAN TOKOH UNTUK MENINGKATKAN HASIL BELAJAR IPS SISWA KELAS V
}

\author{
Sumarni
}

SDN 07 Ulakan Tapakis

\begin{abstract}
Abstratc
The grade V students at SDN 07 Ulakan Tapakis had low attention in social subject learning. It caused their learning achievements came low too. We thought that using graphic media is one of its solutions. Graphic media is a kind of visual media called 2-D media.This is a classroom action research with two cycles. This study is aimed to improve students' learning achievement in social subject. Students got average score of 63.70 in pre cycle. In cycle I, students' average score becomes 68.04 but it is still not satisfied. In cycle II, students' average score improve significantly, i.e. 81.56. Thus, implementation of graphic media can improve the student's learning achievement in social subject.
\end{abstract}

Keyword: card graphic media, social subject, learning achievement

c) (f) This is an open access article distributed under the Creative Commons Attribution License, which permits unrestricted use, distribution, and reproduction in any medium, provided the original work is properly cited. (C2017 by author and IICET.

\section{PENDAHULUAN}

Pendidikan di Sekolah Dasar (SD) merupakan pondasi yang pertama untuk mencapai suksesnya pendidikan selanjutnya, salah satunya pada mata pelajaran Ilmu Pengetahuan Sosial (IPS).Mata pelajaran Ilmu Pengetahuan Sosial (IPS) merupakan salah satu mata pelajaran di sekolah dasar yang tidak mudah menarik perhatian siswa.Dalam Depdiknas (2010:575) dinyatakan bahwa IPS adalah ilmu yang mengkaji seperangkat peristiwa, fakta, konsep, dan generalisasi yang berkaitan dengan ilmu sosial. Berdasarkan hasil pengamatan peneliti dalam mengajarkan mata pelajaran IPS selama ini diketahui bahwa apabila guru tidak menggunakan media, maka siswa akan kurang memperhatikan dan sulit memahami materi yang diajarkan. Hal ini kemudian menyebabkan minat belajar siswa melemah yang mengakibatkan pada rendahnya hasil belajar mereka.Dari hasil pengamatan tersebut, hal ini adalah merupakan masalah yang perlu diatasi.

Guru harus menciptakan pembelajaran yang menyenangkan bagi siswa. Oleh sebab itu, perlu dikembangkan suatu pembelajaran yang tidak membosankan dan membuat siswa lebih tertarik. Media oleh peneliti dalam hal ini 
dianggap sebagai salah satu solusi yang tepat untuk diterapkan. Media merupakan alat pendukung dalam keberhasilan guru dalam mengajar. Menurut Hamalik (1986:7) media adalah "sesuatu alat yang digunakan untuk menyalurkan pesan dari pemberi ke penerima pesan sehingga dapat merangsang pikiran, perasaan, minat dan perhatian siswa". Sedangkan Gagne (dalam Etin, 2007:3) mengartikan media sebagai jenis komponen dalam lingkungan siswa yang dapat merangsang mereka untuk belajar.

Media yang digunakan oleh guru dalam mengajar hendaklah bervariasi. Noorhadi (dalam Mulyani, 2011:183) mengklasifikasikan media sebagai berikut: (1) media visual, contoh: foto, lukisan, gambar dan media grafis lainnya; (2) media audio, contoh: radio dan rekaman suara; (3) media audio visual, contoh: rekaman video, slide suara, dan film. Salah satu dari media visual adalah media grafis yang disebut juga dengan media dua dimensi.

Menurut Arif (2007:28), media grafis adalah media yang berfungsi menyalurkan pesan dari sumber ke penerima pesan, di mana pesan dituangkan melalui lambang atau simbol komunikasi visual. Secara khusus media grafis berfungsi untuk menarik perhatian, memperjelas sajian ide, mengilustrasikan atau menghiasi fakta yang mungkin akan cepat dilupakan atau diabaikan. Mulyani dan Johar mengatakan bahwa media grafis meliputi: (1) gambar; (2) sketsa; (3) diagram; (4) bagan; (5) grafis; (6) kartun; (7) poster, peta, dan globe; serta (8) kartu. Media kartu menurut Enidarwaniswati (2006:14) adalah media yang dibuat dari karton yang tertulis materi-materi pokok dari topik yang dibahas.

Penggunaan media grafis kartu dalam pemberlajaran IPS dapat mengkomunikasikan gagasan-gagasan secara jelas dalam pembelajaran. Media grafis kartu dirancang sesuai dengan tujuan pembelajaran yang ingin dicapai, di mana masing-masing siswa memperoleh satu kartu yang berisi satu pertanyaan yang harus dijawab sesuai dengan materi yang dipelajari, menjelaskan dengan kata-kata sendiri berdasarkan fakta yang terjadi sehingga dapat membuat siswa lain termotivasi untuk mencobanya. Langkah-langkah pembelajaran dengan media grafis kartu meliputi: penyampaian tujuan pembelajaran, menugaskan siswa membaca materi, membagi siswa duduk berkelompok, meletakkan kartu di tengah siswa, menugaskan siswa mengacak dan mengambil kartu, menerangkan cara bermain kartu, menceritakan uraian jawaban dari soal, menugaskan siswa lain menanggapi penjelasan dari siswa yang menjelaskan materi pada kartu, dan memberikan penilaian.

\section{METODE}

Penelitian ini dilaksanakan di kelas VSDN 07 Ulakan Tapakis. Lokasi ini dipilih sebagai tempat penelitian dengan pertimbangan peneliti diamanahkan tugas tambahan sebagai Kepala Sekolah di sini dan mengambil mata pelajaran IPS sebagai jam wajib guru.Subjek dalam penelitian ini adalah siswa kelas V, yang terdaftar pada semester ganjil tahun ajaran 2016/2017, dengan jumlah siswanya 21orang.Jenis penelitian ini adalah penelitian tindakan kelas yaitu proses yang dilakukan perorangan atau kelompok yang menghendaki perubahan dalam situasi tertentu. Penelitian ini terdiri dari dua siklusdengan materi menghargai jasa dan peran tokoh di sekitar proklamasi kemerdekaan.

Penelitian ini diawali dengan adanya observasi awal atau studi pendahuluan terhadap proses pembelajaran di kelas V SDN 07 Ulakan Tapakis. Kegiatan ini dilaksanakan untuk mengetahui permasalahan yang dihadapi guru dan siswa yang berkaitan dengan proses pembelajaran IPS di kelas tersebut. Studi pendahuluan dilakukan dengan mengamati proses pembelajaran di kelas. Kemudian peneliti merumuskan permasalahan yang akan diangkat sebagai permasalahan penelitian yakni, peningkatan hasil belajar IPS dengan menggunakan media kartu grafis pada materi menghargai jasa dan peranan tokoh. Nilai rata-rata siswa sebelum dimulai penelitian adalah 63,70.

\section{HASIL DAN PEMBAHASAN}

\section{Hasil}

Deskripsi Siklus I

\section{Perencanaan}


Penggunaan media grafis kartu dalam perencanaan pembelajaran IPS disusun dan diwujudkan dalam bentukRencana Pelaksanaan Pembelajaran (RPP), soal tes, dan lembar observasi. Perencanaan ini disusun berdasarkan program semester sesuai dengan penelitian berlangsung.

\section{Pelaksanaan}

Siklus I dilaksanakan dalam dua kali pertemuan. Setiap pertemuan tersebut terdiri atas tahap pendahuluan, tahap inti, dan tahap penutup.

\section{Pengamatan}

Pembelajaran pada pertemuan I siklus I ini diamati oleh kepala sekolah selaku peneliti dan juga guru kelas tersebut. Pengamatan berlangsung dengan menggunakan bantuaan lembar observasi. Pengamatan ini dilakukan secara berkelanjutan mulai dari tindakan awal pada petemuan I sampai tindakan akhir pada petemuan II. Hal ini dikarenakan oleh pengamatan terhadap satu tindakan akan berpengaruh pada tindakan yang lainnya. Hasil pengamatan ini kemudian direfleksi untuk perencanaan pada siklus II.

Observasi keberhasilan tindakan diamati selama dan sesudah tindakan dilaksanakan. Hal ini dilaksanakan untuk mendapatkan informasi dari observer terhadap pelaksanaan pembelajaran pada siklus I baik pelaksanaan, evaluasi dan hasil yang diperoleh oleh siswa.Berdasarkan pengamatan observer hasil diskusi dengan peneliti, pada tindakan siklus I ditemukan masih ada siswa yang belum ikut secara aktif dalam pembelajaran.

Keadaan kelas memang agak ribut dan waktu banyak terbuang untuk mengatur siswa dan siswa masih ada yang belum aktif mengikuti kegiatan pembelajaran.Namun demikian, secara umum ditemukan bahwa siswa secara klasikal terlihat lebih tertarik belajar dengan media grafis kartu. Evaluasi hasil belajar yang diperoleh pada siklus I mencapai 68,04.

\section{Refleksi}

Refleksi dilihat dari hasil paparan siklus I dan diketahui bahwa perencanaan pembelajaran terlaksana dengan cukup baik. Sebahagian dari langkah pada perencanaan terlaksana sesuai dengan yang diinginkan. Tapi terdapat beberapa langkah yang tidak berjalan baik. Contohnya, pada awal pembelajaran pembentukan kelompok menghabiskan waktu yang cukup lama.Dalam hal ini peneliti dan guru sebagai pengamat mengadakan diskusi terhadap tindakan yang baru dilakukan.Hal-hal yang di diskusikan adalah (1) menganalisis tindakan yang baru dilakukan, (2) mengulas dan menjelaskan perbedaan rencana dan pelaksanaan tindakan yang telah dilakukan, (3) melakukan intervensi, pemaknaan, dan penyimpulan data yang diperoleh.Hasil refleksi dimanfaatkan sebagai masukan pada tindakan selanjutnya.Berdasarkan hasil refleksi, maka ditetapkan bahwa penelitian dilanjutkan ke siklus II.

\section{Deskripsi Siklus II}

\section{Perencanaan}

Berdasarkan hasil tindakan dari siklus I yang telah diuraikan di atas maka pada siklus II ini tindakan yang akan dilaksanakan yaknimemperjelas penyampaian tujuan pembelajaran agar siswa lebih memahami materi yang akan diajarkan, berusaha memaksimalkan pemakaian waktu dalam pembelajaran sesuai dengan rencana pembelajaran, serta lebih memotivasi siswa agar dapat ikut aktif berdiskusi dalam kelompok.

\section{Pelaksanaan}

Siklus II dilaksanakan dalam satu kali pertemuan. Pertemuan ini juga terdiri atas tahap pendahuluan, tahap inti, dan tahap penutup.

\section{Pengamatan}

Peneliti dan guru mengenal, dan mendokumentasikan semua indikator dari proses hasil perubahan yang terjadi, baik yang disebabkan oleh tindakan terencana maupun dampak intervensi dalam pembelajaran IPS berdasarkan penggunaan media grafis kartu..Hasil pengamatan direkam dalam bentuk lembar observasi.Evaluasi hasil yang diperoleh pada siklus II yaitu 81,56, mengalami peningkatan yang sangat signifikan dibandingkan dengan tes pada siklus I. 


\section{Refleksi}

Kegiatan refleksi dilakukan secara kolaboratif antara peneliti dan guru. Pada kesempatan ini temuan dan hasil pengamatan peneliti dibahas bersama. Refleksi tindakan siklus II ini mencakup refleksi terhadap perencanaan, pelaksanaan, evaluasi dan hasil yang diperoleh oleh siswa. Refleksi terhadap perencanaan yakni sebagai berikut: dilihat dari paparan siklus II diketahui bahwa perencanaan pembelajaran sudah lebih baik dari siklus I, serta dilaksanakan sesuai dengan langkah-langkah yang tertulis dalam perencanaan.Dari hasil belajar siswa yang meningkat, karena tidak ditemukan lagi siswa yang memperoleh nilai $<70$. Nilai anak hanya berkisar di atas 70-100 dengan nilai rata-rata siswa 81,56.Jadi, dapatdisimpulkan bahwa penelitian dalam pembelajaran siklus II telah melaksanakan tugas dengan baik. Dengan demikian penelitian ini berhenti pada siklus II dan tidak dilanjutkan pada siklus berikutnya.

\section{Pembahasan}

\section{Siklus I}

Dari hasil penelitian pelaksanaan pembelajaran dengan menggunakan media grafis kartu pada pembelajaran IPS kelas V terungkap bahwa guru membuat rancangan pembelajaran dalam bentuk Rencana Pelaksanaan Pembelajaran.Susanto (2007:167) mengatakan bahwa "Rencana Pelaksanaan Pembelajaran (RPP) adalah penjabaran siklus kedalam unit satu kegiatan pembelajaran untuk dilaksanakan di kelas.Rencana pelaksanaan pembelajaran merupakan rencana operasional pembelajaran yang memuat beberapa indikator yang terkait untuk dilaksanakan dalam satu atau beberapa kali pertemuan".

Berdasarkan perencanaan yang disusun ini pelaksanaan pembelajaran dilaksanakan sesuai dengan apa yang telah direncanakan, yang mana siklus I disajikan dalam dua kali pertemuan (6x35 menit). Pelaksanaan pembelajaran dengan menggunakan media grafis kartu dapat dijelaskan sebagai berikut: a) Menyampaikan tujuan pembelajaran. Dari hasil penelitian bahwa pada siklus I guru kurang jelas dalam menyampaikan tujuan pembelajaran disebabkan bahasa yang digunakan guru kurang jelas dan terlalu cepat sehingga siswa tidak termotifasi untuk belajar. Sebagaimana kita ketahui menyampaikan tujuan pembelajaran dapat membangkitkan skemata siswa dengan menggali pengetahuan dan pengalaman siswa yang berkaitan dengan materi yang akan dipelajari. Karena itu perlu perbaikan pembelajaran pada siklus ke II. b) Siswa membaca materi. Pada saat siswa membaca materi tidak sebaik diharapkan yangg mana pada pertemua satu, sewaktu siswa membaca materi masih ada siswa yang tidak membaca terlihat siswa hanya membolak balik buku, sehingga siswa kurang memahami makna dari materi yang dibacanya. Sedangkan pada pertemuan kedua sudah terjadi perubahan, siswa sudah mulai membaca dengan serius walaupun terlihat satu dua orang yang masih berbicara dengan teman sebangkunya sehingga mengganggu konsentrasi teman lain yang membaca. c) Membagi siswa duduk berkelompok.

Untuk lebih membuat siswa lebih berkonsentrasi terhadap materi guru membagi siswa duduk berkelompok yang terdiri dari 5 orang siswa, kelompok disusun berdasarkan kemampuan akademik siswa agar siswa yang kemampuan lebih dapat membantu teman yang mempunyai kemampuan rendah, sehingga adanya kerjasama dalam menyelesaikan soal yang didapat dan materi pelajaran akan dapat terkuasai. Nama kelompok diberi nama dengan nama tumbuh-tumbuhan seperti anggrek, magga, melati, dll. d) Meletakkan kartu ditengah siswa. Setelah guru menugasi siswa duduk dalam kelompok, maka guru meletakkan kartu yang berisi soal tentang materi yang telah dibaca siswa ditengah siswa yang telah berkelompok, dimana kartu ini digunakan untuk kegiatan belajar yang akan dilaksanakan. Pada siklus I dalam meletakkan kartu siswa menerima kartu dengan baik cuma siswa agak merasa heran dengan kartu serta bagaimana menggunakan kartu, setelah adanya penjelasan yang diberikan guru siswa mengerti tentang kegunaan dari kartu. e) Menugasi siswa mengacak dan mengambil kartu. Pengacakan kartu dilakukan oleh seorang siswa dalam kelompok kemudian kartu diambil oleh siswa satu perorang dalam kelompok, kemudian siswa mengambil kartu yang telah diacak untuk dikerjakan.

Pada siklus I dalam menugasi siswa mengacak kartu perintah yang digunakan guru jelas siswa mengacak kartu secara keseluruhan, waktu mengambil kartu siswa agak ribut karena ada beberapa siswa yang menukarkan kartu dengan temannya atau merebut kartu temannya.e) Menerangkan cara bermain kartu. Pada siklus I cara guru menyampaikan penjelasan cara bermain kartu cukup jelas sehingga siswa mendengarkan penjelasan guru dengan tenang tetapi waktu menjawab pertanyaan yang ada pada kartu siswa masih ada yang melihat buku. f) Menceritakan uraian jawaban dari soal. Pada pertemuan pertama siklus I siswa masih agak takut atau malu-malu mengungkapkan atau menjelaskan apa yang telah dibuatnya disebabkan jawaban yang dibuatnya salah begitupun 
dengan pertemuan kedua dalam menjelaskan jawaban uraian dari soal siswa agak mengalami kesulitan hal ini disebabkan guru kurang membimbing siswa dalam menjawab soal yang ada pada kartu. g) Siswa lain menanggapi penjelasan.

Pada pertemuan pertama siswa menanggapi penjelasan masih agak kurang disebabkan siswa takut untuk menjelaskanapa yang telah dibuatnya, sedangkan pertemuaan kedua dalam menaggapi penjelasan siswa sudah mulai berani untuk menambahkan atau menanggapi penjelasan dari sola yang dijelaskan temannya sehingga interaksi antar siswa berjalan dengan baik. h) Menugasi siswa lain memberikan penilaian. Pada siklus I kegiatan memberikan nilai tidak berjalan dengan baik karena belum banyaknya siswa yang menjelaskan uraian jawaban dari soal yang dibuat siswa sehingga guru lebih meningkatkan pembelajaran pada siklus ke II.Pada akhir pembelajaran guru membagikan soal evaluasi berupa objektif dan esai pada siswa untuk melihat sampai dimana kemampuan siswa mengingat materi yang telah dipelajarinya sesuai dengan waktu yang diberikan. Dari hasil belajar siswa pada siklus I rata-rata yang diperoleh siswa adalah 68,04. Untuk itu tindakan dilanjutkan pada siklus ke II dengan tujuan agar pembelajaran bisa dikuasai siswa dan rata-rata yang didapat lebih baik dari siklus satu.

\section{Siklus II}

Pelaksanaan pembelajaran dengan menggunakan media grafis kartu dapat dijelaskan sebagai berikut: a) Menyampaikan tujuan pembelajaran. Pada siklus kedua ini guru dalam menyampaikan tujuan pembelajaran sudah baik dan jelas sehingga siswa serius dalam menjelaskan penjelasan yang diberikan guru hal ini disebabkan karena dalam menyampaikan tujuan pembelajaran bahasa yang digunakan mudah pahami dan dimengerti sehingga siswa dapat memahami tujuan pembelajaran tersebut dengan baik. b) Siswa membaca materi. Untuk menguji kemampuan siswa terhadap materi yang telah dibaca maka, guru melakukan tanya jawab terhadap materi yang telah dibaca tersebut. Pada kegiatan ini sudah berjalan dengan baik dimana siswa terlihat serius mengerjakan apa yang diperintahkan guru dan dalam bertanya jawab siswa menjawab pertanyaan yang dilontarkan guru berdasarkan apa yang telah pelajarinya.

Dengan adanya tanya jawab yang dilakukan guru kepada siswa akan dapat membangun pengetahuan siswa tentang materi yang telah dipelajari karena dengan adanya pertanyaan sedikit demi sedikit pengetahuan siswa akan muncul. c) Membagi siswa duduk berkelompok. Sebelum belajar dalam kelompok maka guru membagi siswa kedalam kelompok kecil yang anggotanya terdiri dari 5 orang perkelompok. Kelompok disusun berdasarkan kemampuan akademik siswa agar siswa yang kemampuan lebih dapat membantu teman yang mempunyai kemampuan rendah, sehingga adanya kerjasama dalam menyelesaikan soal yang didapat dan materi pelajaran akan dapat terkuasai. Pada kegiatan ini siswa tidak ribut lagi dalam pembagian kelompok karena pada sebelumnya siswa tersebut sudah mengenal masing-masing anggota kelompoknya sehingga guru dengan mudah mengatur masing-masing siswa dengan tertib duduk pada kelompoknya masing-masing tanpa ada keributan. d) Meletakkan kartu di tengah siswa.

Setelah siswa duduk dalam kelompok masing-masing, maka guru meletakkan kartu ditengah masing-masing kelompok yang berisi soal tentang materi yang telah dibaca siswa, dimana kartu ini digunakan untuk kegiatan belajar yang akan dilaksanakan. Pada siklus ke II ini ketika guru meletakkan kartu ditengah masing-masing kelompok tidak ada lagi siswa yang heran melihat kartu tersebut, karena siswa sudah mengenal kegunaan dari kartu tersebut.e) Menugasi siswa mengacak dan mengambil kartu.Pengacakan kartu dilakukan oleh seorang siswa dalam kelompok kemudian kartu diambil oleh siswa satu perorang dalam kelompok, kemudian siswa mengambil kartu yang telah diacak untuk dikerjakan. Pada siklus II siswa mengacak kartu dengan baik karena guru memberikan petunjuk yang jelas cara mengacak kartu tersebut yaitu mengacak secara keseluruhan.

Pada waktu mengambil kartu tidak ada siswa yang ribut karena masing-masing siswa sudah mendapat kartu yang akan dikerjakannya. f) Menerangkan cara bermain kartu. Pada pertemuan siklus II guru sudah memberikan penjelasan yang jelas tentang cara bermain kartu sehingga tidak ada lagi siswa yang ribut untuk manyakan cara bermain kartu. g) Menceritakan uraian jawaban dari soal. Pada siklus ke II siswa sudah berani untuk mengungkapkan atau menjelaskan apa yang telah dibuatnya, ini terlihat siswa sudah banyak yang mengangkat tangan untuk menjelaskan jawaban soal yang telah dibuatnya pada kartu sehingga suasana kelas menjadi hidup dan bergirah. h) Siswa lain menanggapi penjelasan.

Pada siklus II ini siswa sudah aktif menanggapi penjelasan terhadap uraian soal yang telah dijelaskan temannya, secara berebutan dan mengangkat tangan ingin memberikan penjelasan dan tambahan dari jawaban 
kartu yang telah dibuatnya.i) Menugasi siswa lain memberikan penilaian. Pada siklus II ini siswa sudah memberikan penilaian dengan baik terhadap uraian jawaban soal yang telah di jelaskan oleh temannya hal ini disebabkan karena adanya bimbingan dari guru, sehingga siswa tersebut dapat dengan jelas memberikan penilaian terhadap jawaban dari temannya, dimana dengan penilaian ini akan dapat membangkitkan motivasi siswa lain untuk berusaha lebih baik lagi dalam menjawab uraian dari soal tersebut.

Dari hasil analisis penelitian siklus II sudah mencapai nilai rata-rata kelas sebesar 81,56. Berdasarkan hasil pengamatan siklus II yang diperoleh maka pelaksanaan siklus II sudah baik dan guru sudah berhasil dalam usaha peningkatan hasil belajar siswa dalam pembelajaran menghargai jasa dan peranan tokoh dalam memproklamasikan kemerdekaan dengan menggunakan media grafis kartu bagi siswa kelas V SDN 07 Ulakan Tapakis. Penggunaan media dalam pembelajaran membuat pembelajaran yang dilakukan akan lebih bermakna, dimana siswa menjadi aktif dan kreatif dalam belajar, sehingga dapat meningkatkan hasil belajar, sesuai dengan pendapat Azhar (2003:2), yaitu "proses pembelajaran yang terjadi di sekolah dapat lebih dinamis dan akan mencapai sasaran yang diinginkan jika ditambahkan alat bantu atau media karena dengan menggunakan alat bantu atau media tersebut menjadikan siswa dapat lebih memahami pelajaran".

\section{SIMPULAN DAN SARAN}

Berdasarkan pada paparan data, hasil penelitian dan pembahasan tentang pembelajaran IPS dengan menggunakan media grafis kartu, maka dapat disimpulkan sebagai berikut: (1) Sebelum melakukan pembelajaran guru terlihat dahulu guru perlu membuat rancangan pelaksanaan pembelajaran sesuai dengan langkah-langkah pembelajaran. Rancangan Pelaksaan Pembelajaran (RPP) dengan menggunakan media grafis kartu terdapat standar kompetensi, kompetensi dasar, indikator, tujuan pembelajaran, materi pokok, kegiatan pembelajaran, metode/sumber/media, serta evaluasi; (2) Pelaksanaan pembelajaran IPS dengan penggunaan media grafis kartu diawali dengan menyampaikan tujuan pembelajaran, manyajikan dan membentuk kelompok untuk menjelaskan jawaban dari soal yang ada pada kartu yang membuat siswa dapat mengingat materi yang telah dipelajari, menjelaskan, mengungkapkan ide-ide yang ada serta melatih siswa berani berbicara dan mengeluarkan pendapatnya; (3) Pembelajaran dengan pengguanaan media grafis kartu dapat meningkatkan hasil belajar siswa yang terlihat pada rata-rata hasil belajar siklus II lebih meingkat dari siklus I, dimana pada siklus I rata-rata yang didapat 68,04. Sedangkan siklus II rata-rata yang didapat adalah 81,56.

Berdasarkan kesimpulan yang telah diperoleh dalam penelitian ini, diajukan beberapa saran untuk dipertimbangkan: (1) Bentuk pembelajaran IPS dengan menggunakan media grafis kartu layak dipertimbangkan oleh guru untuk menjadi pembelajaran alternatif yang dapat digunakan sebagai referensi dalam memilih media pembelajaran; (2) Bagi guru yang ingin menerapkan pembelajaran dengan menggunakan media grafis kartu, disarankan memperhatikan hal-hal seperti materi pembelajaran yang tepat, kreatifitas dalam merancang pembelajaran, memberikan bimbingan dan motivasi belajar secara sungguh-sungguh kepada siswa yang berkemampuan kurang dan pasif; dan (3) Bagi peneliti selanjutnya disarankan untuk melakukan kajian mendalam tentang penerapan media pembelajaran grafs kartu pada materi lain dalam matematika.

\section{DAFTAR RUJUKAN}

Arikunto, Suharsimi. (2002). Prosedur Penelitian Suatu Pendekatan Praktek. Jakarta: Rineka Cipta.

Azhar, Arsyad. (2003). Media Pembelajaran. Jakarta: PT Raja Grafindo Persada.

Depdiknas. (2006). Kurikulum Tingkat Satuan Pendidikan Jenjang Pendidikan Dasar. Jakarta: Depdiknas.

Enidarwaniswati. (2006). Peningkatan Proses dan Hasil Belajar IPS Melalui Media Visual di Kelas VI.Skripsi (tidak diterbitkan). FIP UNP.

Hamalik, Oemar. (1986). Media Pendidikan. Bandung.

Hamalik. (1990). Pendekatan Baru Strategi Belajar Mengajar Berdasarkan CBSA. Bandung: CV. Sinar Baru Algensindo. 
Madya, Suwarsih. (2008). Penelitian Tindakan Kelas I. (Online) http://ktiguru.org/index.php/ptk-1 (diakses 18 agustus 2016).

Mahjudin, Ritawati. (2001). Penggunaan Pendekatan Konstruktivisme dalam Pembelajaran Membaca Pemahaman Bagi Siswa SDN Sumber Sari III Kec.Lowokwaru/Kodya Malang. Malang. Universitas Negeri Malang.

Masniladevi. (2003). Keefektifan Belajar Kooperatif Model STAD pada Penjumlahan Pecahan. Malang: Universitas Negeri Malang.

Nurhadi dkk. (2003). Pembelajaran Kontekstual (Contextual Teaching and Learning CTL) dan Penerapannya dalam KBK. Malang. Universitas Negeri Malang.

Purwanto. (1996). Psikologi Pendidikan. Bandung: Remaja Rosdakarya.

Sadiman, Arif S. dkk. (2007). Media Pendidikan: Pengertian dan Pemanfaatannya. Jakarta: PT Raja Grafindo Persada.

Sanjaya, Wina. (2006). Strategi Pembelajaran. Jakarta: Wina Kencana Group.

Solihatin, Etin. (2007). Cooperative Learning: Analisis Pembelajaran IPS. Jakarta: Bumi Aksara.

Sudjana, Nana. (1997). Media Pengajaran. Bandung: Sinar Baru.

Sumantri, Mulyania dan Johar Permana. Bandung. Jakarta: Depdikbud.

Susanto. (2007). Pengembangan KTSP dengan Perspektif Manajemen Visi. Jakarta: Mata Dewa.

Wiraatmaja, Rochiati. (2007). Metode Penelitian Tindakan Kelas. Bandung: PT. Remaja Rosda Karya. 